\title{
A new framework for ranking Critical Success Factors for International Construction Projects
}

DOI 10.2478/otmcj-2021-0030

Received: May 14, 2021; Accepted: September 30, 2021

\begin{abstract}
Due to the wide range of opportunities, collaborations, and challenges offered by the international construction sector, interest in international construction is on the rise. Construction companies must be able to carry out international construction projects (ICPs) more effectively and efficiently. However, executing ICPs is more challenging than executing domestic construction projects. Considering the peculiarities of the construction industry and the associated complexity of construction projects, construction companies should decide on international capability and the selection of an ICP through a careful evaluation of their critical success factors (CSFs). Most of the previous research deals with the concept of CSFs in the context of project management in general, but few studies have identified CSFs for ICPs. To fill that gap in current research, the main objective of this study was to identify and group CSFs for ICPs. A total of 37 CSFs were identified after conducting a detailed literature review and a pre-pilot study. A new framework of CSFs for ICPs was proposed following primary research, which was conducted through in-depth interviews with leading experts in international projects. Although the constructability/ complexity factor of the project received the highest rating in terms of importance to the success of the ICP, the next most critical factors were found to be external factors, such as local contractor/subcontractor, investor, and presence of a foreign partner. The results of this research may help participants involved in ICPs to improve their understanding of the international construction environment and deliver more successful ICPs.
\end{abstract}

Keywords: international construction projects, critical success factors, project management, construction sector

\footnotetext{
*Corresponding author: Lana Lovrenčić Butković, University of Zagreb Faculty of Civil Engineering, Zagreb, Croatia,

E-mail: llovrencic@grad.hr
}

\section{Introduction}

At one time or another, every company thinks about the possibility of expanding into new, foreign markets. The rise of the global construction business and the fall of traditional trade barriers have attracted contractors to diversify into the international marketplace (Ye et al. 2018). When Croatia entered European Union in 2013, its construction market became an open arena for many foreign construction firms, but on the other hand, Croatian construction firms got a chance to compete in the international market. Although Croatian construction companies had a very successful history in the last century, in the recent past such good results were not recorded abroad.

As globalization offers new opportunities to construction companies, it is necessary to ensure that international construction projects (ICPs) are carried out more effectively and efficiently. However, delivering ICPs is more challenging than delivering construction projects domestically. ICPs are those projects in which the contractor, the lead consultant, or the employer is not of the same residence and at least one of them works outside their country of origin (Chan and Suen 2005). Considering the peculiarities of the construction industry and the associated complexity of construction projects, construction companies should decide on international capability and the selection of an ICP through a careful evaluation of their critical success factors (CSFs). The firms must understand fully, with the help of a robust evaluation process, the critical factors affecting the success of an international project (Tang et al. 2012). Although the concept of CSFs was initially introduced to determine the information needs of organizational managers (Khandelwal and Ferguson 1999), the use of the CSF concept has now grown in all areas of management. The study of factors affecting project success has received special and continuous attention over the past decades. In the context of project management, a CSF in a project is a valid circumstance (requirement) of particular importance of the project (IPMA 2015). According to Zhang (2005), CSFs are factors 
that combine to determine the success or failure of an infrastructure project in terms of its objectives.

Most of the previous research deals with the concept of CSFs in the context of project management in general (Belassi and Tukel 1996; Ofori 2003; Chen et al. 2012; Yong and Mustaffa 2013; Alias, et al. 2014; Fortune and White 2006). But this concept found its place in the construction project management (CPM) as well, which is proven by several studies also in this area (Gudienè et al. 2014; Wawak et al. 2020; Mathar et al. 2020; Banihashemi et al. 2017) and gain continual attention in different research topics among CPM. For instance, CSFs for sustainable construction projects (Shen et al. 2017; Xue et al. 2018; Li et al. 2019; Mavi and Standing 2018; Xue et al. 2018), Private Public Partnership (PPP) / Build-Operate-Transfer (BOT) projects (Qiao et al. 2001; Li et al. 2005; Zou et al. 2014; Osei-Kyei et al. 2017; Ahmadabadi and Heravi 2019) as well as in the context of innovation in construction projects (Liu et al. 2016) have been investigated by previous researchers. From the review of previous studies, it is evident that the majority of the existing research on CSFs has focused on construction projects in general, but only a few studies have identified CSFs for ICPs.

This study contributes to the field of project management by addressing the ICPs with the CSF concept and focuses on the identification and hierarchical structuring of CSFs of ICPs. Literature review and expert interviews were used to identify the list of these CSFs. The results can help those involved in ICPs to improve their understanding of the international construction environment and deliver ICPs more successfully. The paper is organized as follows. In the next section, a theoretical background of the concept of CSFs concerning CPM and ICPs is provided. Then, the methodology of the study is presented, followed by the results and discussion, and the conclusion at the end.

\section{Literature review}

From the review of previous studies, it appears that the majority of existing research on CSFs has focused on project management and, in particular, CPM. However, interest in international construction is increasing due to the wide range of opportunities, collaborations, and challenges presented by the international construction sector so recently, and a few studies have investigated and identified CSFs that could lead to the success of ICPs. In this section, a brief literature review of CSFs related to CPM and ICPs is presented.

\subsection{CSFs related to the CPM}

Since the concept of CSFs has been researched, the results of most studies have shown that the greatest use of this concept is in the field of project management (Belassi and Tukel 1996; Cooke-Davies 2002; Saqib et al. 2008; Ika et al. 2012; Pandremmenou et al. 2013; Yalegama et al. 2016; Das and Ngacho 2017; Luckmann and Feldmann 2017; Mavi and Standing 2018). According to Kannan (2018), the concept of CSFs provides a smarter way to identify certain factors that must or must not be present in or excluded from the project, to make a successful project. Among the first studies of CSFs in the project management literature was that of Belassi and Tukel (1996). They focused on the CSFs that influence project success or failure and proposed a new framework for determining CSFs in projects consisting of four groups: factors related to the project, factors related to the project manager and team members, factors related to the organization, and factors related to the external environment. Their research was conducted in six industries and the results showed that top management support is one of the most CSFs. Among the factors related to the project manager, coordination and competence were found to be critical, and among the factors related to the project team members, technical background and commitment were the most critical. Environmental factors such as technology, economy, and the client were also found to be critical and have a statistically significant relationship with construction projects.

From then, many authors have explored the critical factors that lead to project success in general, so a large number of studies can also be found in the field of CPM (Chan et al. 2004; Arain and Asif 2010; Gudienè et al. 2013; Wondimu et al. 2016; Mavi and Standing 2018; Banihashemi et al. 2017; Zou et al. 2014; Pal et al. 2017; Liu et al. 2016; Yu et al. 2018). Considering that construction is a project-oriented activity and the business of the construction company can be viewed across projects, it is justified to use the concept of CSFs in the management of construction projects. The results of previous research have shown that there are several factors that can influence project success. This is particularly pronounced in construction projects due to their specificity and complexity. Many researchers have classified the success factors into specific groups according to selected criteria.

Chan et al. (2004) developed a conceptual framework on CSFs of construction projects based on the literature review of seven major journals in the construction field. Five groups of CSFs, namely project-related factors, project procedures, project management actions, human-related 
factors, and external environment were identified as critical to project success. Nguyen et al. (2004) analyzed 109 large construction projects in Vietnam and the results revealed that the success factors for large construction projects can be grouped into four categories, here referred to as the four COMs: Comfort, Competence, Commitment, and Communication. Of the 20 success factors included in this research, 5 were identified as critical: competent project manager, adequate funding to project completion, multidisciplinary/competent project team, commitment to the project, and availability of resources.

In the study by Saqib et al. (2008), 77 factors that could be critical to the success of construction projects were selected and categorized into seven groups. The results of the study showed that the most important CSFs, in descending order of importance, are: decision-making effectiveness, project manager's experience, contractor's cash flow, contractor experience, the timely decision by owner/owner's representative, site management, supervision, planning effort, prior project management experience and client's ability to make a decision. Another conceptual model that contains grouped CSFs that influence project success was developed by Gudienè et al. (2014). They described seven main groups of factors namely external factors, institutional factors, project-related factors, project management/team-related factors, project manager-related factors, client-related factors, and contractor-related factors that influence project success. The most important CSFs for construction project success based on the three main criteria (time, cost, and quality) were identified in the research by Arain and Asif (2010). The top five CSFs for overall project success included clearly defined project mission, objective and scope, adequate planning and control techniques, owner satisfaction with the developed project, adequacy of plans and specifications, and lack of legal encumbrances.

The concept of CSF also found its place in special research areas among CPM. In the context of innovation in construction projects, Liu et al.'s (2016) study identified 20 CSFs - owner involvement and leadership, top management commitment, and strategic importance of the innovation project. In the work of Mavi and Standing (2018), five groups of CSFs were identified concerning sustainable project management. For material procurement to improve waste minimization in construction projects, the procurement process is characterized by four features: supplier commitment to low-waste measures, low-waste purchasing management, effective material supply management, and waste-efficient bill of quantities (Ajayi and Oyedele 2018). From the review of previous studies, it is evident that the majority of the existing research on CSFs has focused on construction projects in general, but few studies have identified CSFs for ICPs.

\subsection{CSFs characteristic for the ICPs}

Previous studies dealing with the CSFs of international business, particularly ICPs, have not been nearly as comprehensive as those on the factors that influence overall project success. In the past, there have been few studies on this topic. Among the first studies of international construction was that of Mawhinney (2001). In his book, he identified some CSFs for ICPs, such as partners, safety and security measures, social and cultural issues, and estimating costs. Han et al. (2007) analyzed the causes of poor profits in overseas construction projects. Zhao et al. (2009) defined some important factors that influence the internationalization of Chinese construction projects. Their study showed that the Chinese government plays an important role in the internationalization of construction companies' business, as it strongly supports and helps to promote companies abroad. Another study, that by Chen and Orr (2009), showed that the most important factors for the success of business abroad are good infrastructure, the ability to finance the project, and the availability of natural resources in the target market. Han et al (2010) pointed out that uncertain and aggressive changes in the global construction sector pose a serious threat to all participants in ICP.

But in the last decade, an interest in the field of ICPs has been increased. CSFs, which impact international engineering, procurement, and construction (IEPC) project success to the greatest extent, are service provided by suppliers and/or subcontractors, continuous improvement, supplier and/or subcontractor delivery reliability, and effective problem solving (Pal et al. 2017). In the work of Alashwal et al. (2017) among Malaysian contractors, factors such as team power and skills, resource availability, external environment, organization capability, project support, and project organization were found to be most significant for ICPs. One of the most important factors affecting the success of ICPs can certainly be singled out as being related to cultural differences between countries. For example, Chan and Tse (2003) analyzed the international activities of construction companies in a cultural context and showed that cultural differences are the most critical factor in conducting international activities. The importance of understanding cultural differences and taking appropriate actions to achieve project delivery of international projects was also studied by Pheng and Leong (2000). They used construction projects in China 
to show how cross-cultural management can affect the outcome of projects. There is limited but growing research examining critical risk factors that influence the success of ICPs (e.g. Razzaq et al. 2018; Viswanathan and Jha 2020).

As some research has shown (eg. Mohamed 2003; Kwok et al. 2000; Khamaksorn et al. 2020), for construction companies operating internationally, the most popular strategy and the one that contributes most to risk reduction is the international joint venture (IJV), especially with a local partner. Bing and Tiong (1999) categorized the key success factors for an international construction joint venture (ICJV) into seven groups: partner selection, contracting, recruitment, control, subcontracting, good connections, and negotiation. Mohamed (2003) investigated several IJV projects between the UK and Australian construction companies. His research aimed to investigate the links between risk, key success factors, and execution. The results showed that selecting a local partner and adopting a proactive risk management strategy are keys to successful IJV. A study by Razzaq et al (2018) identified the 16 critical external risks in IJVs. They were classified into five groups: political, economic, legal, social, and environmental risks.

\section{Research methodology}

\subsection{Phase 1: CSFs identification}

The most common CSFs that influence the implementation and success of ICPs were identified through a detailed literature search that included articles from various databases such as ScienceDirect, Scopus, Google Scholar, etc. There were four common categories/groups of CSFs highlighted in the literature with a total of 56 CSF indicators. These identified CSFs with references are presented in Table 1.

\subsection{Phase 2: Pre-pilot research}

In Phase 2, semi-structured interviews were conducted with experts to adapt the preliminary list of CSFs from Phase 1 in the context of ICPs. The target respondents for the interviews were construction management professionals with relevant experience in international business. 10 experts were invited to participate in this phase of the research, as shown in Table 2. In the first part of the interview, the interviewees were asked for general information about their company and their previous international experience. The interviewees in this phase had an average international experience of 18 years and all of them were involved in the decision-making process about internationalization of their company.

In the second part of this pre-pilot survey, questions focused on a specific international project in which the respondent was personally involved and the factors that were critical to that project. Respondents ranked the critical factors previously identified in the literature in order of importance concerning a particular international project using the card sorting method (Appendix 1). Respondents also suggested some additional factors that were critical from their experience and that had not been identified in the literature reviewed. In the end, a list of 37 CSFs emerged that were found to be crucial in the implementation of international projects.

Table 3 shows the list of CSFs for which the level of agreement that they were critical or potentially critical was $>50 \%$. Other factors where the percentage of agreement was $<50 \%$, are such as uniqueness of project activities, language barriers, completion of the project on time, quality of work, technical solutions, and some others were excluded from further analysis. Based on the interviews, in the next phase of primary research, some external or organizational factors were included, which were suggested by the respondents themselves, such as the presence of a foreign partner, local companies/ subcontractors, the investor, legislation in the country of implementation, and company references. Based on these results of the pre-pilot study, a final list of CSFs was formed, consisting of 37 factors. The CSFs were grouped into four groups, namely project-related factors, human factors, organizational factors, and external factors, and this grouping was adjusted according to previous research on determining the factors that influence project success.

\subsection{Phase 3: Pilot research}

Before the final design of the questionnaire, a pilot study was conducted on the list of CSFs for ICPs. The purpose of this pilot study was to ensure the validity and reliability of the designed questions and measurement scales. A questionnaire was designed with $37 \mathrm{CSF}$ identified from the extensive literature review and the results of the pre-pilot study. The reliability of the measurement scales was analyzed by the coefficient Cronbach's alpha and Corrected-Item Total Correlation (CITC) indicator (Churchill 1979). 
Tab. 1: CSFs indicators for the success of ICPs identified from relevant literature

\begin{tabular}{ll}
\hline CSF indicators & Author(s) \\
\hline Project-related factors &
\end{tabular}

1 Project size and value

2 Project characteristics/Uniqueness of project activities

3 Constructability/Complexity

4 Site management

5 Accurate initial cost estimates

6 Formal dispute resolution process

7 Adequate funding throughout the project

8 Effective project planning and control

9 IT support for project management

10 Language barriers

11 Appropriate project identification

12 Effective project management

13 Completion of the project on time

14 Quality of the work

15 Innovative technical approaches

\section{Human-related factors}

16 Organizing skills of project manager

17 Coordinating ability of project manager

18 Project manager's competency

19 Communication skills of project manager

20 Project manager's experience

21 Education level of the project manager

22 Political connections of the project manager

23 Decision-making ability of project manager

24 Leadership skills of project manager

25 Motivating skills of project manager
Belassi and Tukel 1996; Chan et al. 2004; Fortune and White 2006; Arain and Asif 2010; Khan and Spang 2011; Gudienè et al. 2014, Inayat et al. 2015; Alashwal et al. 2017; Shen et al. 2017; Mavi and Standing 2018; Mathar et al. 2020

Belassi and Tukel 1996; Chen et al. 2012, Gudienė et al. 2014

Saqib et al. 2008; Arain and Asif 2010; Yong and Mustaffa 2013, Gudienè et al. 2014; Mavi and Standing 2018; Mathar et al. 2020

Arain and Asif 2010; Yong and Mustaffa 2013; Ghanbaripour et al. 2020, Mathar et al. 2020

Nguyen et al. 2004; Arain and Asif 2010

Saqib et al. 2008; Arain and Asif 2010; Pal et al. 2017; Mathar et al. 2020

Nguyen et al. 2004; Fortune and White 2006; Arain and Asif 2010; Yong and Mustaffa 2013; Gudienė et al. 2014; Li et al. 2019; Ghanbaripour et al. 2020

Chan et al. 2004; Nguyen et al. 2004; Saqib et al. 2008; Fortune and White 2006; Toor and Ogunlana 2009; Arain and Asif 2010; Gudienè et al. 2014, Mavi and Standing 2018; Li et al. 2019

Pandit and Zhu 2007; Toor and Ogunlana 2009; Mathar et al. 2020

Belassi and Tukel 1996

Qiao et al. 2001

Belassi and Tukel 1996

Belassi and Tukel 1996

Belassi and Tukel 1996

Belassi and Tukel 1996; Khan and Spang 2011; Gudienė et al. 2014; Shen et al. 2017; Li et al. 2019

Saqib et al. 2008; Gudienė et al. 2014; Alashwal et al. 2017

Belassi and Tukel 1996; Chan et al. 2004; Saqib et al. 2008; Gudienė et al. 2014

Belassi and Tukel 1996; Chan et al. 2004; Nguyen et al. 2004; Fortune and White 2006; Saqib et al. 2008; Khan and Spang 2011; Yong and Mustaffa 2013; Gudienè et al. 2014; Bayiley and Teklu 2016; Alashwal et al. 2017; Banihashemi et al. 2017; Shen et al. 2017; Mavi and Standing 2018; Li et al. 2019; Ghanbaripour et al. 2020; Mathar et al. 2020

Arslan and Kivrak 2008; Gudienė et al. 2014

Ogunlana et al. 2002; Fortune and White 2006; Pheng and Chuan 2006; Saqib et al. 2008; Gudienè et al. 2014

Arslan and Kivrak 2008

Arslan and Kivrak 2008

Saqib et al. 2008

Arslan and Kivrak 2008; Saqib et al. 2008; Yong and Mustaffa 2013; Gudienè et al. 2014

Chan et al. 2004; Saqib et al. 2008; Gudienè et al. 2014 
Tab. 1: Continued

\begin{tabular}{|c|c|c|}
\hline & CSF indicators & Author(s) \\
\hline 26 & $\begin{array}{l}\text { Project manager's adaptability to } \\
\text { changes in the project plan }\end{array}$ & Saqib et al. 2008; Yong and Mustaffa 2013; Gudienė et al. 2014; Banihashemi et al. 2017 \\
\hline 27 & $\begin{array}{l}\text { Project manager's ability for risk } \\
\text { identification }\end{array}$ & Gudienè et al. 2014; Banihashemi et al. 2017 \\
\hline 28 & $\begin{array}{l}\text { Technical background of project team } \\
\text { members }\end{array}$ & Belassi and Tukel 1996; Gudienė et al. 2014; Alashwal et al. 2017; Mathar et al. 2020 \\
\hline 29 & $\begin{array}{l}\text { Communication skills of project team } \\
\text { members }\end{array}$ & $\begin{array}{l}\text { Belassi and Tukel 1996; Ofori 2003; Gudienè et al. 2014; Alashwal et al. 2017; Shen et al. } \\
2017\end{array}$ \\
\hline 30 & Commitment & $\begin{array}{l}\text { Belassi and Tukel 1996; Arain and Asif 2010; Khan and Spang 2011; Alashwal et al. 2017; } \\
\text { Mavi and Standing 2018; Mathar et al. } 2020\end{array}$ \\
\hline 31 & $\begin{array}{l}\text { Troubleshooting skills of project team } \\
\text { members (problem-solving) }\end{array}$ & $\begin{array}{l}\text { Belassi and Tukel 1996; Saqib et al. 2008; Gudienè et al. 2014; Liu et al. 2016; Alashwal et } \\
\text { al. 2017; Pal et al. } 2017\end{array}$ \\
\hline 32 & $\begin{array}{l}\text { Effective relationship among project } \\
\text { team members }\end{array}$ & Arslan and Kivrak 2008; Liu et al. 2016; Banihashemi et al. 2017 \\
\hline 33 & Multidisciplinary team & Qiao et al. 2001; Nguyen et al. 2004; Ghanbaripour et al. 2020 \\
\hline 34 & Multinational team & Qiao et al. 2001 \\
\hline \multicolumn{3}{|c|}{ Organizational factors } \\
\hline 35 & Top management support & $\begin{array}{l}\text { Belassi and Tukel 1996; Cooke-Davies 2002; Ofori 2003; Nguyen et al. 2004; Toor and } \\
\text { Ogunlana 2009; Khan and Spang 2011; Yong and Mustaffa 2013; Liu et al. 2016; Alashwal } \\
\text { et al. 2017; Mavi and Standing 2018; Li et al. 2019; Ghanbaripour et al. } 2020\end{array}$ \\
\hline 36 & Organizational structure & $\begin{array}{l}\text { Belassi and Tukel 1996; Fortune and White 2006; Saqib et al. 2008; Khan and Spang 2011; } \\
\text { Banihashemi et al. 2017; Mavi and Standing 2018 }\end{array}$ \\
\hline 37 & Functional managers support & Belassi and Tukel 1996 \\
\hline 38 & Company's flexibility & Arain and Asif 2010 \\
\hline 39 & $\begin{array}{l}\text { Good business/government relation- } \\
\text { ships }\end{array}$ & Qiao et al. 2001; Arain and Asif 2010 \\
\hline 40 & Comprehensive contract documentation & $\begin{array}{l}\text { Nguyen et al. 2004; Arain and Asif 2010; Yong and Mustaffa 2013; Banihashemi et al. 2017; } \\
\text { Ahmadabadi and Heravi } 2019\end{array}$ \\
\hline 41 & Quality control & Qiao et al. 2001; Saqib et al. 2008; Arain and Asif 2010; Mathar et al. 2020 \\
\hline 42 & Effective project monitoring and control & $\begin{array}{l}\text { Kwak 2002; Ofori 2003; Arslan and Kivrak 2008; Arain and Asif 2010; Khan and Spang } \\
\text { 2011; Mavi and Standing 2018; Mathar et al. } 2020\end{array}$ \\
\hline 43 & Clear goals and objectives & $\begin{array}{l}\text { Ofori 2003; Nguyen et al. 2004; Fortune and White 2006; Arain and Asif 2010; Mavi and } \\
\text { Standing 2018; Li et al. 2019; Mathar et al. } 2020\end{array}$ \\
\hline 44 & Control of cash-flow & Arslan and Kivrak 2008; Mathar et al. 2020 \\
\hline 45 & Strong financing capacity & Arslan and Kivrak 2008; Alashwal et al. 2017; Ghanbaripour et al. 2020 \\
\hline 46 & Effective organizing and planning & $\begin{array}{l}\text { Nguyen et al. 2004; Arslan and Kivrak 2008; Arain and Asif 2010; Banihashemi et al. 2017; } \\
\text { Mathar et al. } 2020\end{array}$ \\
\hline 47 & Risk management & $\begin{array}{l}\text { Arslan and Kivrak 2008; Saqib et al. 2008; Khan and Spang 2011; Mavi and Standing 2018; } \\
\text { Li et al. 2019; Mathar et al. } 2020\end{array}$ \\
\hline 48 & Follow and adopt new technologies & Ofori 2003; Arslan and Kivrak 2008; Chen et al. 2012 \\
\hline 49 & Skillful workers & Arslan and Kivrak 2008; Yong and Mustaffa 2013; Alashwal et al. 2017 \\
\hline 50 & Cost management & Ofori 2003; Arslan and Kivrak 2008; Yong and Mustaffa 2013 \\
\hline
\end{tabular}


Tab. 1: Continued

\begin{tabular}{|c|c|c|}
\hline & CSF indicators & Author(s) \\
\hline \multicolumn{3}{|c|}{ External factors } \\
\hline 51 & Economic and politic environment & $\begin{array}{l}\text { Belassi and Tukel 1996; Qiao et al. 2001; Kwak 2002; Chan et al. 2004; Saqib et al. 2008; } \\
\text { Khan and Spang 2011; Yong and Mustaffa 2013; Alashwal et al. 2017; Banihashemi et al. } \\
\text { 2017; Shen et al. 2017; Mavi and Standing 2018; Razzaq et al. 2018; Ahmadabadi and } \\
\text { Heravi } 2019\end{array}$ \\
\hline 52 & Financial environment & $\begin{array}{l}\text { Qiao et al. 2001; Alashwal et al. 2017; Mavi and Standing 2018; Ahmadabadi and Heravi } \\
2019\end{array}$ \\
\hline 53 & $\begin{array}{l}\text { Regularity of construction market and } \\
\text { legislation }\end{array}$ & $\begin{array}{l}\text { Qiao et al. 2001; Kwak 2002; Bayiley and Teklu 2016; Mavi and Standing 2018; Razzaq et } \\
\text { al. } 2018\end{array}$ \\
\hline 54 & Level of competition & Belassi and Tukel 1996; Arslan and Kivrak 2008; Yong and Mustaffa 2013 \\
\hline 55 & Company experience in selected market & Arslan and Kivrak 2008; Yong and Mustaffa 2013; Surlan et al. 2016; Mathar et al. 2020 \\
\hline 56 & $\begin{array}{l}\text { Competitive tendering system in } \\
\text { selected market }\end{array}$ & Qiao et al. 2001; Chen et al. 2012; Yong and Mustaffa 2013 \\
\hline
\end{tabular}

CSFs, critical success factors; ICPs, international construction projects.

Tab. 2: Profile of participants in the pre-pilot research

\begin{tabular}{llccr}
\hline ID & Position & $\begin{array}{c}\text { Experience in international } \\
\text { business (years) }\end{array}$ & $\begin{array}{c}\text { Number of foreign countries } \\
\text { participated in }\end{array}$ & $\begin{array}{c}\text { Number of ICPs } \\
\text { involved in }\end{array}$ \\
\hline Interviewee 1 & Project manager & 24 & 5 & 12 \\
Interviewee 2 & CEO & 40 & 5 & 26 \\
Interviewee 3 & Technical director & 32 & 3 & 20 \\
Interviewee 4 & CEO & 6 & 6 & 8 \\
Interviewee 5 & Retired PM & 30 & 36 & 12 \\
Interviewee 6 & Project manager & 5 & 8 & 8 \\
Interviewee 7 & Project manager & 7 & 2 & 4 \\
Interviewee 8 & CEO & 6 & 5 & 2 \\
Interviewee 9 & CEO & 16 & 3 & 10 \\
Interviewee 10 & CEO & 14 & 5 \\
\hline
\end{tabular}

ICPs, international construction projects.

The collected data were imported into SPSS Statistics 22 and all values of Cronbach's alpha for the CSF items are $>0.9$ and none of the items had a negative CITC indicator, indicating a relatively high level of internal reliability (Hair et al. 2009).

In addition, the study tested for normality and atypical variables (outliers). According to Hair et al. (2009), an objective test for testing normality is the calculation of the skewness index and the kurtosis index. In this study, normality was first assessed by the Shapiro-Wilk test, as it was assumed to be appropriate for $\mathrm{n}<50$ samples and additionally by skewness and kurtosis indices with subjective histogram assessment. The results also showed that none of the tested variables deviated from normal or permissible values. Accordingly, all CSF items were included in the final questionnaire (Appendix 2).

\subsection{Phase 4: Interviews}

The primary research was conducted through in-depth interviews with 35 leading experts who were involved in decisions to internationalize their companies or as project managers of international projects from December 2019 to February 2020. The interviews used questions in the form of a semi-structured questionnaire and were conducted using the Computer Assitant Personal Interview (CAPI) method, which allowed respondents to answer questions with computer assistance. The interview was divided into two sections; the first section asked for the interviewees' background data and the second section included the CSFs (defined in earlier stages of the present research) concerning an ICP, expressed on a 5-point Likert scale from 1 (not critical at all) to 5 
(very critical). In this second part of the interview, respondents were asked to rate CSFs offered concerning a specific international project in which they had personally participated.

Tab. 3: Final list of CSFs for the success of ICPS

\begin{tabular}{|c|c|c|}
\hline Group & Variable & CSFs \\
\hline \multirow{10}{*}{ 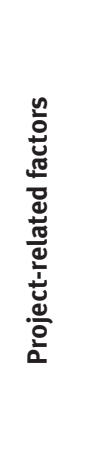 } & CSF-P-1 & Project size and value \\
\hline & CSF-P-2 & Constructability/Complexity \\
\hline & CSF-P-3 & Site management \\
\hline & CSF-P-4 & Accurate initial cost estimates \\
\hline & CSF-P-5 & The formal dispute resolution process \\
\hline & CSF-P-6 & Adequate funding throughout the project \\
\hline & CSF-P-7 & Effective project planning and control \\
\hline & CSF-P-8 & IT support for project management \\
\hline & CSF-P-9 & Appropriate project identification \\
\hline & CSF-P-10 & Effective project management \\
\hline \multirow{8}{*}{ 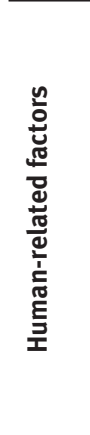 } & CSF-H-1 & Project manager's competency \\
\hline & CSF-H-2 & Project manager's experience \\
\hline & CSF-H-3 & Decision-making ability of project manager \\
\hline & CSF-H-4 & Leadership skills of project manager \\
\hline & CSF-H-5 & $\begin{array}{l}\text { Project manager's adaptability to make } \\
\text { changes in the project plan }\end{array}$ \\
\hline & CSF-H-6 & Commitment \\
\hline & CSF-H-7 & $\begin{array}{l}\text { Troubleshooting skills of project team } \\
\text { members (problem-solving) }\end{array}$ \\
\hline & CSF-H-8 & Multidisciplinary team \\
\hline \multirow{10}{*}{ 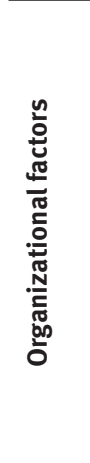 } & CSF-0-1 & Top management support \\
\hline & CSF-0-2 & Company’s flexibility \\
\hline & CSF-0-3 & Comprehensive contract documentation \\
\hline & CSF-0-4 & Quality control \\
\hline & CSF-0-5 & Effective project monitoring and control \\
\hline & CSF-0-6 & Clear goals and objectives \\
\hline & CSF-0-7 & Strong financing capacity \\
\hline & CSF-0-8 & Effective organizing and planning \\
\hline & CSF-0-9 & Company references \\
\hline & CSF-0-10 & Company experience in selected market \\
\hline \multirow{9}{*}{ 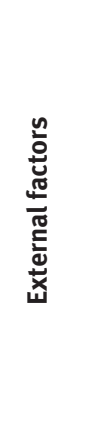 } & CSF-E-1 & Economic conditions in the host country \\
\hline & CSF-E-2 & Financial conditions in the host country \\
\hline & CSF-E-3 & Regularity of construction market \\
\hline & CSF-E-4 & Level of competition in the host country \\
\hline & CSF-E-5 & Legislation in the host country \\
\hline & CSF-E-6 & $\begin{array}{l}\text { Public procurement system in the host } \\
\text { country }\end{array}$ \\
\hline & CSF-E-7 & Investor \\
\hline & CSF-E-8 & Existence of a foreign partner \\
\hline & CSF-E-9 & Local construction companies/subcontractors \\
\hline
\end{tabular}

CSFs, critical success factors; ICPs, interational construction projects.

\section{Results and discussion}

\subsection{Respondents profile}

The demographic information of the respondents is presented in Table 4. It shows that the majority of the respondents work in a company that acts as a contractor in foreign markets (74.3\%) and another $25.7 \%$ were consultants. Regarding the distribution of company years of international work experience, $14.3 \%$ had $<5$ years of experience, $20.0 \%$ had between 5 years and 10 years of experience, $28.6 \%$ had between 10 years and 20 years of experience, and $37.1 \%$ had $>20$ years of experience in international markets. In terms of the number of ICPs their company was involved in, $22.9 \%$ participated in $<10$ projects, $51.4 \%$ participated in between 10 and 20 projects, and $25.7 \%$ participated in $>20$ international projects.

Other demographic questions asked were about specific ICPs in which a respondent was involved. Most ICPs were public projects (65.7\%), private projects accounted for $22.9 \%$, followed by PPP projects (11.4\%). Most of the analyzed ICPs were located in non-EU member countries (45.7\%), including Serbia, Bosnia, and Herzegovina, Montenegro,

Tab. 4: Profile of the respondents

\begin{tabular}{lrc}
\hline Variables & Frequency & Percentage (\%) \\
\hline Company role & & \\
Constructor & 26 & 74.3 \\
Consultant & 9 & 25.7 \\
Company type & & \\
Small & 16 & 45.7 \\
Medium & 5 & 14.3 \\
Large & 14 & 40.0 \\
International experience (years) & & \\
5 & 5 & 14.3 \\
$5-10$ & 7 & 20.0 \\
10-20 & 10 & 28.6 \\
20 & 13 & 37.1 \\
Number of ICPs & & \\
10 & 8 & 22.9 \\
10-20 & 18 & 51.4 \\
20 & 9 & 25.7 \\
Type of ICP & & \\
Private & 8 & 22.9 \\
Public & 23 & 65.7 \\
PPP & 4 & 11.4 \\
Location of ICP & & \\
EU members & 10 & 28.6 \\
Non EU members & 5 & 11.4 \\
Africa & 4 & \\
Asia & 5.7 \\
\hline
\end{tabular}

ICPs, international construction projects. 
and Kosovo. EU member countries accounted for $28.6 \%$ of the projects, followed by Africa (14.3\%) and Asia (11.4\%). Finally, it is interesting to note that 25 of the surveyed companies already had the experience of participating in projects in the country where the observed project was carried out, and also 29 companies subsequently concluded new projects and continued their business in that country.

\subsection{Data analysis}

An assessment of the significance of the CSFs concerning the ICPs was calculated using the s-factor. In this study, a 5-point Likert scale ranging from 1 (not at all critical) to 5 (very critical) was used to evaluate the CSFs. This methodology is adapted from the work of Edum-Fotwe and McCaffer (2000). A similar methodology for ranking CSFs for large building projects was also used by Mathar et al. (2020). The perceived level of critical rank for each factor was determined by applying Eq. (1).

$s-$ factor $=100 * \Sigma \mathrm{x}_{\mathrm{i}} \mathrm{f}_{\mathrm{i}} /\left(\mathrm{x}_{\max } * \Sigma \mathrm{f}_{\mathrm{i}}\right)$

where: $i$ takes a value between 1 and 5 based on the adopted nominal scale; $x_{i}$ represents discrete categories of scaled respondent attitudes; $x_{\max }$ the maximum value of $\mathrm{x}_{\mathrm{i}} ; \mathrm{f}_{\mathrm{i}}$ represents the frequency for each category of $\mathrm{x}_{\mathrm{i}} ; \Sigma \mathrm{f}_{\mathrm{i}}$ represents the total sample size for each CSF. Values of the s-factor ranged from 100 to 0 , with higher values indicating higher levels of criticality.

According to the participants' assessment of CSFs, it can be seen that the most important is the group of external factors with an s-factor of $>70$, followed by organizational and project factors (Table 5). This study also elicited the relative importance for each capability and based on this, the final results were analyzed and discussed. Table 6. shows the resulting s-factors associated with each CSF. The results showed that none of the CSFs listed in the questionnaire received an s-factor of $<50$, so all 37 CSFs identified in this study could be important for the success of ICPs. A new framework of CSFs associated with ICP success is presented in Figure 1. The results show the

Tab. 5: CSF group ranking

\begin{tabular}{lc}
\hline Generic group of CSFs & s-factor \\
\hline Project- related factors & 67.7 \\
Human- related factors & 66.8 \\
Organizational factors & 70.8 \\
External factors & 71.9 \\
\hline
\end{tabular}

CSFs, critical success factors. important role of external factors in the success of construction projects, especially in the international market, as two factors from this group have an s-factor $>80.0$. These results are consistent with the findings from the work of Razzaq et al. (2018), which suggest that external risks are associated with the success of ICP. However, even though this research focused on ICPs, the most critical factor is the one related to the characteristics of the project itself, its constructability/complexity.

\section{Discussion}

\subsection{External factors}

The results of this study show that the most important group of CSFs are the external factors with the highest overall mean and s-factor value. This is in line with the findings of the work of Razzaq et al. (2018) who indicated that external risks are associated with the success of ICP. This study identified some very important external factors that could be critical to the success of ICPs. Within this group, there are two CSFs with an s-factor >80: Local contractor/subcontractor) (CSF-E-9) and Investor (CSF-E-9) Given the complexity of a construction project, subcontractors are often hired to complete a specific portion of the project. When managing an international project, contractors consider hiring local firms, which may impact the ultimate success of the project (especially if there is not enough qualified local labor or local firms do not meet the prime contractor/project manager criteria). These criteria were identified by the contractors in the first phase of the study as critical in overseas projects and were included in the final list of CSFs on their recommendation. For the same reason, the investor, if from the host country, emerged as the second most important CSF for ICPs among the external factors and third overall. The third most important external factor is the presence of a foreign partner (CSF-E-8), mainly because a local partner could facilitate the implementation of a project, followed by the regularity of the construction market (CSF-E-5) and legislation in the host country (CSF-E-3). The first three factors were unique findings of this study, while the other factors were consistent with previous studies.

\subsection{Organizational factors}

Organizational factors were found to be the second most important group of CSFs for ICP success, mainly because 
Tab. 6: Ranking of CSFs related to the success of ICPS

\begin{tabular}{|c|c|c|c|c|c|c|}
\hline Group of CSFs & Code & Mean & SD & $s$-factor & Group rank & Overall rank \\
\hline \multirow{10}{*}{ 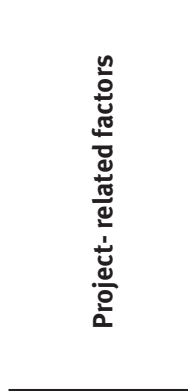 } & CSF-P-1 & 3.00 & 1.26 & 60.0 & 9 & 34 \\
\hline & CSF-P-2 & 4.11 & 0.98 & 82.3 & 1 & 1 \\
\hline & CSF-P-3 & 3.54 & 0.87 & 70.9 & 2 & 14 \\
\hline & CSF-P-4 & 3.54 & 0.81 & 70.9 & 3 & 15 \\
\hline & CSF-P-5 & 3.03 & 1.11 & 60.6 & 8 & 33 \\
\hline & CSF-P-6 & 3.37 & 0.93 & 67.4 & 7 & 25 \\
\hline & CSF-P-7 & 3.46 & 1.27 & 69.1 & 6 & 20 \\
\hline & CSF-P-8 & 2.74 & 0.94 & 54.9 & 10 & 37 \\
\hline & CSF-P-9 & 3.54 & 0.91 & 70.9 & 4 & 16 \\
\hline & CSF-P-10 & 3.49 & 1.34 & 69.7 & 5 & 18 \\
\hline \multirow{8}{*}{ 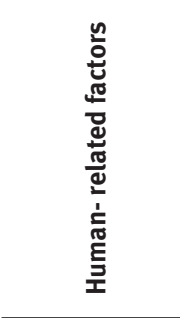 } & CSF-H-1 & 3.46 & 0.97 & 78.3 & 1 & 5 \\
\hline & CSF-H-2 & 3.66 & 1.24 & 73.1 & 2 & 11 \\
\hline & CSF-H-3 & 3.40 & 1.13 & 68.0 & 4 & 24 \\
\hline & CSF-H-4 & 3.57 & 1.10 & 71.4 & 3 & 13 \\
\hline & CSF-H-5 & 2.91 & 0.87 & 58.3 & 8 & 36 \\
\hline & CSF-H-6 & 3.09 & 1.02 & 61.7 & 6 & 31 \\
\hline & CSF-H-7 & 3.11 & 1.14 & 62.3 & 5 & 30 \\
\hline & CSF-H-8 & 3.06 & 1.07 & 61.1 & 7 & 32 \\
\hline \multirow{10}{*}{ 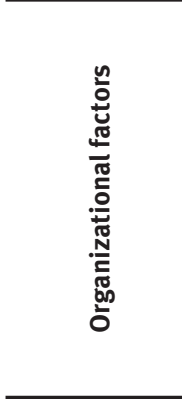 } & CSF-O-1 & 3.71 & 1.21 & 74.3 & 2 & 7 \\
\hline & CSF-O-2 & 3.34 & 1.07 & 66.9 & 9 & 28 \\
\hline & CSF-0-3 & 3.23 & 0.90 & 64.6 & 10 & 29 \\
\hline & CSF-0-4 & 3.71 & 0.97 & 74.3 & 3 & 8 \\
\hline & CSF-O-5 & 3.43 & 1.15 & 68.6 & 8 & 23 \\
\hline & CSF-0-6 & 3.46 & 0.81 & 69.1 & 6 & 21 \\
\hline & CSF-0-7 & 3.63 & 1.12 & 72.6 & 5 & 12 \\
\hline & CSF-0-8 & 3.74 & 0.87 & 74.9 & 1 & 6 \\
\hline & CSF-0-9 & 3.69 & 1.43 & 73.7 & 4 & 9 \\
\hline & CSF-0-10 & 3.46 & 0.84 & 69.1 & 7 & 22 \\
\hline \multirow{9}{*}{ 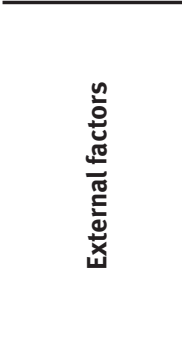 } & CSF-E-1 & 3.37 & 0.76 & 67.4 & 7 & 26 \\
\hline & CSF-E-2 & 3.49 & 0.73 & 69.7 & 6 & 19 \\
\hline & CSF-E-3 & 3.54 & 0.84 & 70.9 & 5 & 17 \\
\hline & CSF-E-4 & 3.37 & 0.93 & 67.4 & 8 & 27 \\
\hline & CSF-E-5 & 3.69 & 0.89 & 73.7 & 4 & 10 \\
\hline & CSF-E-6 & 2.94 & 1.17 & 58.9 & 9 & 35 \\
\hline & CSF-E-7 & 4.00 & 1.01 & 80.0 & 2 & 3 \\
\hline & CSF-E-8 & 3.89 & 0.82 & 78.9 & 3 & 4 \\
\hline & CSF-E-9 & 4.03 & 1.08 & 80.6 & 1 & 2 \\
\hline
\end{tabular}

CSFs, critical success factors; ICPs, international construction projects.

of the support needed at each stage of international business. The most important CSF is effective organization and planning (CSF-O-8). If the company has not defined a strategy that includes targeting and diversifying into new international markets, as well as does not have the necessary resources, ICP success will fail to materialize. Top management support (CSF-O-1) was ranked as the second critical factor for ICP success. The results show that quality control (CSF-O-4) is the third most important CSF at the organizational level, followed by company's references (CSF-0-9) and the strong financing capacity of the firm (CSF-O-7). It is obvious that in international business, support from the whole company is much more necessary than in domestic projects.

\subsection{Project-related factors}

As mentioned earlier, the construction sector is a project-oriented industry, so it is not surprising that project-related factors are also very important for the success of ICPs. The most important CSF in this group of factors is the constructability/complexity of the project (CSF-P-2) and also in the whole research. The second most important 


\section{Project-related factors:} Constructability/Complexity Site management Accurate initial cost estimates Appropriate project identification Effective project management Effective project planning and control Adequate funding throughout the project Formal dispute resolution process Project size \& value IT support for project management

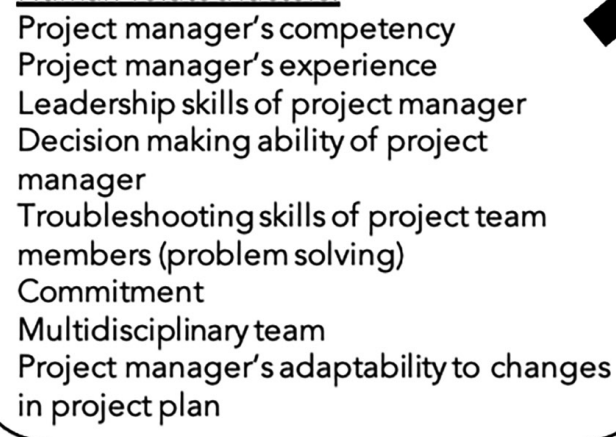

\section{Organizational factors: \\ Effective organizing and planning Top management support \\ Quality control \\ Company references \\ Strong financing capacity \\ Clear goals and objectives}

Company experience in selected market Effective project monitoring and control Company's flexibility Comprehensive contract documentation

Fig. 1: A new framework of CSFs related to the success of ICPs. CSFs, critical success factors; ICPs, international construction projects.

CSF concerning the project is site management (CSF-P-3). Since site organization is a critical factor for the project in general (Ghanbaripour et al. 2020; Mathar et al. 2020), the findings of this research suggest that it could also be critical for ICPs. Since the construction products are static, remain at the place of manufacture, and many parties are involved in the construction, the site organization must be consistent with defined schedules, costs, and quality. In addition, accurate initial cost estimating (CSF-P-4), as one of the three major criteria for project success, was found to be the third most important factor among project-related factors for ICP success. Other factors such as appropriate project identification (CSF-P-9) and effective project management (CSF-P-10) were also found to be significant in the context of international projects.

\subsection{Human-related factors}

In this group of factors that could be critical to the success of ICPs, the factors that were assessed were those related to the project manager and the project team (humanrelated factors). Human-related factors were found to be the least important in this research, but when considering project management in general, and therefore ICPs, there is no question about the importance of the factors identified in this group. If project stakeholders can better predict the likelihood of success, they can take steps to avoid unsuccessful projects, identify good projects worth pursuing, and identify problems on current projects and take corrective action (Saqib et al. 2008). The most significant CSF from this research is project manager competency (CSF-H-1), which is consistent with much previous research (e.g. Khan and Spang 2011; Alashwal et al. 2017; Mavi and Standing 2018). The second most important CSF is the project manager's experience (CSF-H-2), followed by the roject manager's leadership skills (CSF-H-4) and the project manager's decision-making ability (CSF-P-3).

\section{Conclusion}

Today, to achieve a long-term and sustainable competitive advantage, a company must align itself with the global marketplace. For all the peculiarities of the construction 
industry and therefore construction companies, it is undeniable that entering foreign and global markets is a major challenge. The concept of CSF is becoming increasingly important for any company, especially in the area of strategic management and project management. Since construction companies are project-oriented businesses, the application of the CSF concept is considered justified in the construction industry.

Through a thorough and critical review of the literature and after conducting a pre-pilot study, a total of 37 CSFs were identified. The list of factors consisted of factors identified in the literature as well as factors suggested by respondents in a pre-pilot study. Primary research was conducted through in-depth interviews with 35 leading experts who were involved in internationalization decisions of their companies or as project managers of international projects. When evaluating groups of factors, the results showed that the most critical group is that of external factors, which mainly relate to the external environment of the host country. The most critical factors in this group were external factors such as the local contractor/subcontractor, the investor, and the presence of a foreign partner. These factors were unique findings of this study, while the other factors were consistent with previous studies. Organizational factors were found to be the second most important group of CSFs for ICP success, such as effective organization and planning, and top management support, mainly because of the support needed at each stage of international business.

The study results also showed that among the 37 CSFs, the most critical factor for international construction project success is the constructability/complexity of the project. Although this study focused on ICP, the characteristics of construction projects, their complexity, and feasibility, still have the most important influence on the success of a project, whether it is undertaken domestically or internationally. Some other project-related factors were found to be significant, which is consistent with the findings of similar research in CPM. People-related factors were found to be least important in this research, but when considering project management in general and therefore ICP, there is no doubt about the importance of factors related to the competence or experience of the project manager. Therefore, all identified factors must be taken into account in international projects, of course with special attention to the external factors that play a major role. The findings of this study may assist participants in ICPs in improving their understanding of the international construction environment and delivering more successful ICPs. Identifying CSFs can also aid in the selection of appropriate strategies for entering foreign markets.

\section{References}

Ahmadabadi, A. A., \& Heravi, G. (2019). The effect of critical success factors on project success in public-private partnership projects: A case study of highway projects in Iran. Transport Policy, 73, pp. 152-161.

Ajayi, S. O., \& Oyedele, L. O. (2018). Waste-efficient materials procurement for construction projects: A structural equation modelling of critical success factors. Waste Management, 75, pp. 60-69.

Alashwal, A. M., Fareed, N. F., \& Al-Obaidi, K. M. (2017). Determining success criteria and success factors for international construction projects for Malaysian contractors. Construction Economics and Building, 17(2), pp. 62-80.

Alias, Z., Zawawi, E. M. A., Yusof, K., \& Aris, N. M. (2014). Determining critical success factors of project management practice: A conceptual framework. Procedia - Social and Behavioral Sciences, 153, pp. 61-69.

Arain, F., \& Asif, M. (2010). Critical Success Factors of Construction Project Management: A Construction Industry Perspective. Lambert Academic Publishing Ag \& Co., Germany.

Arslan, G., \& Kivrak, S. (2008). Critical factors to company success in the construction industry. World Academy of Science, Engineering and Technology, 45(1), pp. 43-46.

Banihashemi, S., Hosseini, M. R., Golizadeh, H., \& Sankaran, S. (2017). Critical success factors (CSFs) for integration of sustainability into construction project management practices in developing countries. International Journal of Project Management, 35(6), pp. 1103-1119.

Bayiley, Y. T., \& Teklu, G. K. (2016). Success factors and criteria in the management of international development projects: Evidence from projects funded by the European Union in Ethiopia. International Journal of Managing Projects in Business, 9(3), pp. 562-582.

Belassi, W., \& Tukel, O. I. (1996). A new framework for determining critical success/failure factors in projects. International Journal of Project Management, 14(3), pp. 141-151.

Bing, L., \& Tiong, R. L. K. (1999). Risk management model for international construction joint ventures. Journal of Construction Engineering and Management, 125(5), pp. 377-384.

Chan, A. P. C., Scott, D., \& Chan, A. P. L. (2004). Factors affecting the success of a construction project. Journal of Construction Engineering and Management, 130(1), pp. 153-155.

Chan, E. H. W., \& Suen, H. C. H. (2005). Dispute resolution management for international construction projects in China. Management Decision, 43(4), pp. 589-602.

Chan, E. H. W., \& Tse, R. Y. C. (2003). Cultural considerations in international construction contracts. Journal of Construction Engineering and Management, 129(4), pp. 375-381.

Chen, C., \& Orr, R. J. (2009). Chinese contractors in Africa: Home government support, coordination mechanisms, and market entry strategies. Journal of Construction Engineering and Management, 135(11), pp. 1201-1210. 
Chen, Y. Q., Zhang, Y. B., Liu, J. Y., \& Mo, P. (2012). Interrelationships among critical success factors of construction projects based on the structural equation model. Journal of Management in Engineering, 28(3), pp. 243-251.

Churchill, G. A. (1979). A paradigm for developing better measures of marketing constructs. Journal of Marketing Research, 16, pp. 64-73.

Cooke-Davies, T. (2002). The "real" success factors on projects. International Journal of Project Management, 20(3), pp. 185-190.

Das, D., \& Ngacho, C. (2017). Critical success factors influencing the performance of development projects: An empirical study of Constituency Development Fund projects in Kenya. IIMB Management Review, 29(4), pp. 276-293.

Edum-Fotwe, F. T., \& McCaffer, R. (2000). Developing project management competency: Perspectives from the construction industry. International Journal of Project Management, 18(2), pp. 111-124.

Fortune, J., \& White, D. (2006). Framing of project critical success factors by a systems model. International Journal of Project Management, 24(1), pp. 53-65.

Ghanbaripour, A. N., Sher, W., \& Yousefi, A. (2020). Critical success factors for subway construction projects - Main contractors' perspectives. International Journal of Construction Management, 20(3), pp. 177-195.

Gudienè, N., Banaitis, A., Banaitienè, N., \& Lopes, J. (2013). Development of a conceptual critical success factors model for construction projects: A case of Lithuania. Procedia Engineering, 57, pp. 392-397.

Gudienè, N., Banaitis, A., Podvezko, V., \& Banaitienè, N. (2014). Identification and evaluation of the critical success factors for construction projects in Lithuania: AHP approach. Journal of Civil Engineering and Management, 20(3), pp. 350-359.

Hair, J. K., Black, W. C., Babin, B. J., \& Anderson, R. E. (2009). Multivariate Data Analysis (7th Edition), Prentice Hall, New Jersey, SAD.

Han, S. H., Kim, D. Y., Jang, H. S., \& Choi, S. (2010). Strategies for contractors to sustain growth in the global construction market. Habitat International, 34(1), pp. 1-10.

Han, S. H., Park, S. H., Kim, D. Y., Kim, H., \& Kang, Y. W. (2007). Causes of bad profit in overseas construction projects. Journal of Construction Engineering and Management, 133(12), pp. 932-943.

Ika, L. A., Diallo, A., \& Thuillier, D. (2012). Critical success factors for world bank projects: An empirical investigation. International Journal of Project Management, 30(1), pp. 105-116.

Inayat, A., Melhem, H., \& Esmaeily, A. (2015). Critical success factors in an agency construction management environment. Journal of Construction Engineering and Management, 141(1), pp. 1-7.

IPMA. (2015) Individual Competence Baseline for Project, Programme \& Portfolio Management, Version 4.0. IPMA - International Project Management Association, Zurich, Switzerland.

Kannan, D. (2018). Role of multiple stakeholders and the critical success factor theory for the sustainable supplier selection process. International Journal of Production Economics, 195, pp. 391-418.

Khamaksorn, A., Tah, J. H. M., \& Kurul, E. (2020). Knowledge creation: A case study of international construction joint venture projects in Thailand. International Journal of Innovation, Management and Technology, 11(1), pp. 10-17.

Khan, R. A., \& Spang, K. (2011). Critical success factors for international projects. In: Proceedings of the 6th IEEE International Conference on Intelligent Data Acquisition and Advanced Computing Systems, IEEE, Prague, Czech Republic, 15-17 September 2011.

Khandelwal, V. K., \& Ferguson, J. R. (1999). Critical success factors (CSFs) and the growth of IT in selected geographic regions. In: Proceedings of the 32nd Annual Hawaii International Conference on Systems Sciences, Maui, HI, USA, IEEE, 5-8 January 1999.

Kwak, Y. H. (2002). Critical success factors in international development project management. In: 10th Symposium Construction Innovation and Global Competitiveness, University of Cincinnati.

Kwok, H.-C. A., Then, D., \& Skitmore, M. (2000). Risk management in Singapore construction joint ventures. Journal of Construction Research, 1(2), pp. 139-149.

Li, B., Akintoye, A., Edwards, P. J., \& Hardcastle, C. (2005). Critical success factors for PPP/PFI projects in the UK construction industry. Construction Management and Economics, 23(5), pp. 459-471.

Li, Y., Song, H., Sang, P., Chen, P.-H., \& Liu, X. (2019). Review of Critical Success Factors (CSFs) for green building projects. Building and Environment, 158, pp. 182-191.

Liu, H., Skibniewski, M. J., \& Wang, M. (2016). Identification and hierarchical structure of critical success factors for innovation in construction projects: Chinese perspective. Journal of Civil Engineering and Management, 22(3), pp. 401-416.

Lückmann, P., \& Feldmann, C. (2017). Success factors for business process improvement projects in small and medium sized enterprises - Empirical evidence. Procedia Computer Science, 121, pp. 439-445.

Mathar, H., Assaf, S., Hassanain, M. A., Abdallah, A., \& Sayed, A. M. Z. (2020). Critical success factors for large building construction projects: Perception of consultants and contractors. Built Environment Project and Asset Management, 10(3), pp. 349-367.

Mavi, R. K., \& Standing, C. (2018). Critical success factors of sustainable project management in construction: A fuzzy DEMATEL-ANP approach. Journal of Cleaner Production, 194, pp. 751-765.

Mawhinney, M. (2001). International Construction. Blackwell Science, Oxford; Malden, MA.

Mohamed, S. (2003). Performance in international construction joint ventures: Modeling perspective. Journal of Construction Engineering and Management, 129(6), pp. 619-626.

Nguyen, L. D., Ogunlana, S. O., \& Lan, D. T. (2004). A study on project success factors on large construction projects in Vietnam. Engineering Construction and Architectural Management, 11(6), pp. 404-413.

Ofori, G. (2003). Frameworks for analysing international construction. Construction Management and Economics, 21(4), pp. 379-391.

Ogunlana, S., Siddiqui, Z., Yisa, S., \& Olomolaiye, P. (2002). Factors and procedures used in matching project managers to construction projects in Bangkok. International Journal of Project Management, 20(5), pp. 385-400. 
Osei-Kyei, R., Chan, A. P. C., Javed, A. A., \& Ameyaw, E. E. (2017). Critical success criteria for public-private partnership projects: International experts' opinion. International Journal of Strategic Property Management, 21(1), pp. 87-100.

Pal, R., Wang, P., \& Liang, X. (2017). The critical factors in managing relationships in international engineering, procurement, and construction (IEPC) projects of Chinese organizations. International Journal of Project Management, 35(7), pp. 1225-1237.

Pandit, A., \& Zhu, Y. (2007). An ontology-based approach to support decision-making for the design of ETO (Engineer-To-Order) products. Automation in Construction, 16(6), pp. 759-770.

Pandremmenou, H., Sirakoulis, K., \& Blanas, N. (2013). Success factors in the management of investment projects: A case study in the region of Thessaly. Procedia - Social and Behavioral Sciences, 74, pp. 438-447.

Pheng, L. S., \& Chuan, Q. T. (2006). Environmental factors and work performance of project managers in the construction industry. International Journal of Project Management, 24(1), pp. 24-37.

Pheng, L. S., \& Leong, C. H. Y. (2000). Cross-cultural project management for international construction in China. International Journal of Project Management, 18(5), pp. 307-316.

Qiao, L., Wang, S. Q., Tiong, R. L. K., \& Chan, T.-S. (2001). Framework for critical success factors of BOT projects in China. The Journal of Structured Finance Spring, 7(1), pp. 53-61.

Razzaq, A., Thaheem, M. J., Maqsoom, A., \& Gabriel, H. F. (2018). Critical external risks in international joint ventures for construction industry in Pakistan. International Journal of Civil Engineering, 16, pp. 189-205.

Saqib, M., Farooqui, R. U., \& Lodi, S. H. (2008). Assessment of critical success factors for construction projects. In: 1st International Conference on Construction in Developing Countries: Advancing and Integrating Construction Education, Research \& Practice, Karachi, Pakistan, 4-5 August 2008.

Shen, W., Tang, W., Siripanan, A., Lei, Z., Duffield, C. F., Wilson, D., et al. (2017). Critical success factors in Thailand's green building industry. Journal of Asian Architecture and Building Engineering, 16(2), pp. 317-324.

Surlan, N., Cekic, Z., \& Torbica, Z. (2016). Use of value management workshops and critical success factors in introducing local experience on the international construction projects. Journal of Civil Engineering and Management, 22(8), pp. 1021-1031.

Tang, L. C. M., Atkinson, B., \& Zou, R. R. (2012). An entropy-based SWOT evaluation process of critical success factors for international market entry: A case study of a medium-sized consulting company. Construction Management and Economics, 30(10), pp. 821-834.

Toor, S., \& Ogunlana, S. O. (2009). Construction professionals' perception of critical success factors for large-scale construction projects. Construction Innovation, 9(2), pp. 149-167.

Viswanathan, S. K., \& Jha, K. N. (2020). Critical risk factors in international construction projects: An Indian perspective. Engineering, Construction and Architectural Management, 27(5), pp. 1169-1190.

Wawak, S., Ljevo, Ž., \& Vukomanović, M. (2020). Understanding the key quality factors in construction projects - A systematic literature review. Sustainability, 12(24), pp. 10376.

Wondimu, P. A., Hailemichael, E., Hosseini, A., Lohne, J., Torp, O., \& Lædre, O. (2016). Success factors for Early Contractor Involvement (ECI) in public infrastructure projects. Energy Procedia, 96, pp. 845-854.

Xue, B., Liu, B., \& Sun, T. (2018). What matters in achieving infrastructure sustainability through project management practices: A preliminary study of critical factors. Sustainability, 10(12), pp. 4421.

Yalegama, S., Chileshe, N., \& Ma, T. (2016). Critical success factors for community-driven development projects: A Sri Lankan community perspective. International Journal of Project Management, 34(4), pp. 643-659.

Ye, M., Lu, W., Flanagan, R., \& Ye, K. (2018). Diversification in the international construction business. Construction Management and Economics, 36(6), pp. 348-361.

Yong, Y. C., \& Mustaffa, N. E. (2013). Critical success factors for Malaysian construction projects: An empirical assessment. Construction Management and Economics, 31(9), pp. 959-978.

Yu, W.-d., Cheng, S.-t., Ho, W.-c., \& Chang, Y.-h. (2018). Measuring the Sustainability of Construction Projects throughout Their Lifecycle: A Taiwan Lesson. Sustainability, 10, 1523.

Zhang, X. (2005). Critical success factors for public-private partnerships in infrastructure development. Journal of Construction Engineering and Management, 131(1), pp. 3-14.

Zhao, Z. Y., Shen, L. Y., \& Zuo, J. (2009). Performance and strategy of chinese contractors in the international market. Journal of Construction Engineering and Management, 135(2), pp. 108-118.

Zou, W., Kumaraswamy, M., Chung, J., \& Wong, J. (2014). Identifying the critical success factors for relationship management in PPP projects. International Journal of Project Management, 32(2), pp. 265-274. 


\section{Appendix 1}

\begin{tabular}{|c|c|c|c|c|}
\hline \multicolumn{2}{|c|}{ CSF indicators } & \multirow{2}{*}{$\begin{array}{l}\text { Not } \\
\text { critical (\%) }\end{array}$} & \multirow{2}{*}{$\begin{array}{l}\text { Potentially } \\
\text { critical (\%) }\end{array}$} & \multirow[t]{2}{*}{ Critical (\%) } \\
\hline \multicolumn{2}{|c|}{ Project-related factors } & & & \\
\hline 1 & Project size and value & 10 & 70 & 20 \\
\hline 2 & Project characteristics/Uniqueness of project activities & 40 & 30 & 30 \\
\hline 3 & Constructability/Complexity & 30 & 10 & 60 \\
\hline 4 & Site management & 30 & 50 & 20 \\
\hline 5 & Accurate initial cost estimates & 30 & 10 & 60 \\
\hline 6 & Formal dispute resolution process & 20 & 70 & 10 \\
\hline 7 & Adequate funding throughout the project & 20 & 30 & 50 \\
\hline 8 & Effective project planning and control & 20 & 70 & 10 \\
\hline 9 & IT support for project management & 40 & 50 & 10 \\
\hline 10 & Language barriers & 60 & 40 & \\
\hline 11 & Appropriate project identification & 10 & 40 & 50 \\
\hline 12 & Effective project management & 20 & 20 & 60 \\
\hline 13 & Completion of the project on time & 20 & 40 & 40 \\
\hline 14 & Quality of the work & 30 & 40 & 30 \\
\hline 15 & Innovative technical approaches & 40 & 30 & 30 \\
\hline
\end{tabular}

\section{Human-related factors}

16 Organizing skills of project manager

17 Coordinating ability of project manager

18 Project manager's competency

19 Communication skills of project manager

20 Project manager's experience

21 Education level of the project manager

22 Political connections of the project manager

23 Decision-making ability of project manager

24 Leadership skills of project manager

25 Motivating skills of project manager

26 Project manager's adaptability to changes in project plan

27 Project manager's ability for risk identification

28 Technical background of project team members

29 Communication skills of project team members

30 Commitment

Troubleshooting skills of project team members (problem-solving)

Effective relationship among project team members

Multidisciplinary team

Multinational team

\begin{tabular}{lll}
40 & 30 & 30 \\
40 & 20 & 40 \\
40 & 10 & 50 \\
50 & 20 & 30 \\
40 & & 60 \\
40 & 20 & 40 \\
10 & 40 & 10 \\
40 & 10 & 50 \\
30 & 20 & 50 \\
40 & 30 & 30 \\
20 & 60 & 20 \\
20 & 40 & 40 \\
30 & 40 & 30 \\
40 & 30 & 30 \\
30 & 20 & 50 \\
30 & 50 & 20 \\
30 & 40 & 30 \\
40 & 10 & 50 \\
50 & 30 & 20 \\
\hline
\end{tabular}

\section{Organizational factors}

$\begin{array}{ll}35 & \text { Top management support } \\ 36 & \text { Organizational structure } \\ 37 & \text { Functional managers support } \\ 38 & \text { Company's flexibility } \\ 39 & \text { Good business/government relationships } \\ 40 & \text { Comprehensive contract documentation } \\ 41 & \text { Quality control } \\ 42 & \text { Effective project monitoring and control } \\ 43 & \text { Clear goals and objectives } \\ 44 & \text { Control of cash-flow } \\ 45 & \text { Strong financing capacity } \\ 46 & \text { Effective organizing and planning }\end{array}$

\begin{tabular}{lll}
30 & 20 & 50 \\
60 & 30 & 10 \\
50 & 40 & 10 \\
30 & 50 & 20 \\
60 & 20 & 20 \\
& 70 & 30 \\
20 & 30 & 50 \\
40 & 40 & 20 \\
10 & 60 & 30 \\
40 & 40 & 20 \\
20 & 20 & 60 \\
20 & 60 & 20 \\
\hline
\end{tabular}


Continued

\begin{tabular}{|c|c|c|c|c|}
\hline \multicolumn{2}{|c|}{ CSF indicators } & \multirow{2}{*}{$\begin{array}{l}\begin{array}{l}\text { Not } \\
\text { critical (\%) }\end{array} \\
10\end{array}$} & \multirow{2}{*}{$\begin{array}{l}\text { Potentially } \\
\text { critical (\%) }\end{array}$} & \multirow{2}{*}{$\begin{array}{l}\text { Critical (\%) } \\
30\end{array}$} \\
\hline 47 & Risk management & & & \\
\hline 48 & Follow and adopt new technologies & 60 & 40 & \\
\hline 49 & Skillful workers & 40 & 40 & 20 \\
\hline 50 & Cost management & 40 & 40 & 20 \\
\hline \multicolumn{5}{|c|}{ External factors } \\
\hline 51 & Economic and politic environment & 30 & 50 & 20 \\
\hline 52 & Financial environment & 30 & 20 & 50 \\
\hline 53 & Regularity of construction market and legislation & 30 & 50 & 20 \\
\hline 54 & Level of competition & 30 & 50 & 20 \\
\hline 55 & Company experience in selected market & 20 & 30 & 50 \\
\hline 56 & Competitive tendering system in selected market & 50 & 30 & 20 \\
\hline
\end{tabular}

\section{Appendix 2}

Reliability tests of CSFs for ICPs:

\begin{tabular}{lcc}
\hline Generic group of CSFs & Cronbach's alpha & No. of items \\
\hline Project- related factors & 0.966 & 10 \\
Human- related factors & 0.979 & 8 \\
Organizational factors & 0.961 & 10 \\
External factors & 0.945 & 9 \\
\hline
\end{tabular}

CSFs, critical success factors; ICPs, international construction projects.

Shapiro-Wilk's test:

\begin{tabular}{lccc}
\hline Generic group of CSFs & Statistic & df & Sig. \\
\hline Project- related factors & 0.942 & 34 & 0.070 \\
Human- related factors & 0.971 & 34 & 0.498 \\
Organizational factors & 0.940 & 34 & 0.094 \\
External factors & 0.959 & 34 & 0.234 \\
\hline
\end{tabular}

CSFs, critical success factors.

Normality tests of CSFs for ICPs:

\begin{tabular}{|c|c|c|c|c|c|}
\hline \multirow[t]{2}{*}{ Group of CSFs } & \multirow[t]{2}{*}{ Code } & \multicolumn{2}{|c|}{ Skewness } & \multicolumn{2}{|c|}{ Kurtosis } \\
\hline & & Statistic & $\begin{array}{c}\text { Stand. } \\
\text { Error }\end{array}$ & Statistic & $\begin{array}{c}\text { Stand. } \\
\text { Error }\end{array}$ \\
\hline \multirow{10}{*}{ 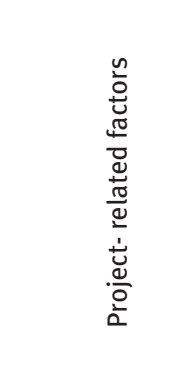 } & CSF-P-1 & 3.00 & 1.26 & 60.0 & 9 \\
\hline & CSF-P-2 & 4.11 & 0.98 & 82.3 & 1 \\
\hline & CSF-P-3 & 3.54 & 0.87 & 70.9 & 2 \\
\hline & CSF-P-4 & 3.54 & 0.81 & 70.9 & 3 \\
\hline & CSF-P-5 & 3.03 & 1.11 & 60.6 & 8 \\
\hline & CSF-P-6 & 3.37 & 0.93 & 67.4 & 7 \\
\hline & CSF-P-7 & 3.46 & 1.27 & 69.1 & 6 \\
\hline & CSF-P-8 & 2.74 & 0.94 & 54.9 & 10 \\
\hline & CSF-P-9 & 3.54 & 0.91 & 70.9 & 4 \\
\hline & CSF-P-10 & 3.49 & 1.34 & 69.7 & 5 \\
\hline
\end{tabular}

Continued

\begin{tabular}{|c|c|c|c|c|c|}
\hline \multirow[t]{2}{*}{ Group of CSFs } & \multirow[t]{2}{*}{ Code } & \multicolumn{2}{|c|}{ Skewness } & \multicolumn{2}{|c|}{ Kurtosis } \\
\hline & & Statistic & $\begin{array}{c}\text { Stand. } \\
\text { Error }\end{array}$ & Statistic & $\begin{array}{c}\text { Stand. } \\
\text { Error }\end{array}$ \\
\hline \multirow{8}{*}{ 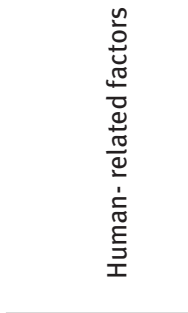 } & CSF-H-1 & 3.46 & 0.97 & 78.3 & 1 \\
\hline & CSF-H-2 & 3.66 & 1.24 & 73.1 & 2 \\
\hline & CSF-H-3 & 3.40 & 1.13 & 68.0 & 4 \\
\hline & CSF-H-4 & 3.57 & 1.10 & 71.4 & 3 \\
\hline & CSF-H-5 & 2.91 & 0.87 & 58.3 & 8 \\
\hline & CSF-H-6 & 3.09 & 1.02 & 61.7 & 6 \\
\hline & CSF-H-7 & 3.11 & 1.14 & 62.3 & 5 \\
\hline & CSF-H-8 & 3.06 & 1.07 & 61.1 & 7 \\
\hline \multirow{10}{*}{ 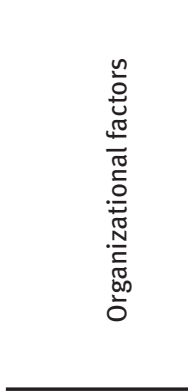 } & CSF-0-1 & 3.71 & 1.21 & 74.3 & 2 \\
\hline & CSF-0-2 & 3.34 & 1.07 & 66.9 & 9 \\
\hline & CSF-0-3 & 3.23 & 0.90 & 64.6 & 10 \\
\hline & CSF-0-4 & 3.71 & 0.97 & 74.3 & 3 \\
\hline & CSF-0-5 & 3.43 & 1.15 & 68.6 & 8 \\
\hline & CSF-0-6 & 3.46 & 0.81 & 69.1 & 6 \\
\hline & CSF-0-7 & 3.63 & 1.12 & 72.6 & 5 \\
\hline & CSF-0-8 & 3.74 & 0.87 & 74.9 & 1 \\
\hline & CSF-0-9 & 3.69 & 1.43 & 73.7 & 4 \\
\hline & CSF-O-10 & 3.46 & 0.84 & 69.1 & 7 \\
\hline \multirow{9}{*}{ 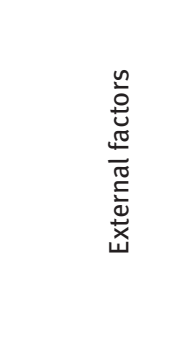 } & CSF-E-1 & 3.37 & 0.76 & 67.4 & 7 \\
\hline & CSF-E-2 & 3.49 & 0.73 & 69.7 & 6 \\
\hline & CSF-E-3 & 3.54 & 0.84 & 70.9 & 5 \\
\hline & CSF-E-4 & 3.37 & 0.93 & 67.4 & 8 \\
\hline & CSF-E-5 & 3.69 & 0.89 & 73.7 & 4 \\
\hline & CSF-E-6 & 2.94 & 1.17 & 58.9 & 9 \\
\hline & CSF-E-7 & 4.00 & 1.01 & 80.0 & 2 \\
\hline & CSF-E-8 & 3.89 & 0.82 & 78.9 & 3 \\
\hline & CSF-E-9 & 4.03 & 1.08 & 80.6 & 1 \\
\hline
\end{tabular}

CSFs, critical success factors; ICPs, international construction projects. 